\title{
A new insight into the influence of habitat on the biochemical properties of three commercial sea cucumber species
}

\author{
Mercedes González-Wangüemert • Christina C. Roggatz • Maria João Rodrigues • \\ Luísa Barreira $\cdot$ Manuela Moreira da Silva $\cdot$ Luísa Custódio
}

Received: 12 May 2018/Accepted: 9 November 2018/Published online: 26 November 2018

(C) The Author(s) 2018

\begin{abstract}
This work makes a comparative evaluation of the biochemical profile of three sea commercial cucumber species (Holothuria mammata, H. polii and H. tubulosa) caught from different locations of the Mediterranean Sea (SE Spain). All species had high levels of moisture (from $73.6 \%$ in H. mammata to $81.2 \%$ in $H$. tubulosa), crude ash (from $9.61 \%$ in $\mathrm{H}$. mammata to $14.7 \%$ in $\mathrm{H}$. tubulosa) and protein $(3.01 \%$ in $\mathrm{H}$. tubulosa to $11.1 \%$ in H. mammata). They also had a low fat content, from $0.21 \%$ in $\mathrm{H}$. tubulosa to $0.55 \%$ in $\mathrm{H}$. mammata. Holothuria polii had intermediate values between the other two species, for all considered variables. All species had adequate protein/lipid ratios (H. mammata, 20:1; H. polii, 23:1; H. tubulosa, 14:1) and low lipid levels, enriched in omega-3 polyunsaturated fatty acids, especially arachidonic acid. The fatty acid profile suggests that $H$. polii is feeding on sediments more influenced by terrestrial inputs than the remaining species. Holothuria mammata and $H$. tubulosa are feeding on marine food sources mainly, but also with some terrestrial influence. The most abundant amino acids detected were alanine, arginine, glutamic acid, and glycine. All species had similar contents of essential amino acids (EAA) and ratios of EAA/non-essential amino acids. Holothuria tubulosa had a high content of toxic metals including $\mathrm{Cr}, \mathrm{Pb}$ and $\mathrm{Ni}$. This work highlights differences in compositional characteristics between different species of the same genus (Holothuria) from different locations.
\end{abstract}

Keywords Bioaccumulation $\cdot$ Fatty acids $\cdot$ Habitat $\cdot$ PUFAs $\cdot$ Toxic minerals

\section{Introduction}

Sea cucumbers (Echinodermata: Holothuroidea) are an important fishery resource, mainly in the Indo-Pacific region. They are exported to different locations, such as Hong Kong and Mainland China, where they are consumed as a dried (bêche-de-mer) or fresh products (Kasai 2003; Purcell et al. 2012; Purcell 2014). In those

M. González-Wangüemert · C. C. Roggatz · M. J. Rodrigues · L. Barreira · L. Custódio ( $\square)$

Center of Marine Sciences, Faculty of Sciences and Technology, University of Algarve, Ed. 7, Campus of Gambelas, 8005-139 Faro, Portugal

e-mail: 1custodio@ualg.pt

C. C. Roggatz

Department of Chemistry, University of Hull, Cottingham Road, Hull HU6 7RX, UK

M. M. da Silva

Center of Marine and Environmental Research (CIMA), University of Algarve, Campus de Gambelas, 8005-139 Faro, Portugal 
Asian markets sea cucumbers are a high value product and can reach up to USD300-500/kg (Purcell 2010; Wen et al. 2010). The global sea cucumber trade aiming the food market is controlled largely by China, Hong Kong SAR, Singapore and Taiwan (Jaquemet and Conand 1999; FAO 2014; INFOPESCA and FAO 2013). However, sea cucumbers are being increasingly exported from Mauritania to the United States (Ann-Marie Holmes personal communication, from US Fish and Wildlife Service, US Department of Interior). Additionally, in Europe the areas and volume of sea cucumber capture are growing (Bordbar et al. 2011; FAO 2011; González-Wangüemert et al. 2016, 2018). The use of sea cucumbers has been mainly to fuel the increasing demand of Maiman based therapies also termed as zootherapies (Mahomoodally and Muthoorah 2014; Mootoosamy and Mahomoodally 2014).

It is estimated that 66 sea cucumber species are caught from more than 40 countries and exported to Asian markets (Conand and Byrne 1993; Choo 2008; Conand 2008; Kinch et al. 2008; Purcell 2010; Purcell et al. 2012). There has been a significant reduction in the sea cucumber stocks in many countries, or even a complete stock depletion in many tropical fisheries caused by the increasing market demand, unrestrained exploitation and/or inadequate fisheries (Purcell et al. 2012). Those situations boosted the catch and commercialization of species from alternative locations such as the Mediterranean Sea, being Holothuria mammata, H. tubulosa and H. polii some of the new target species (Aydin 2008; Aydin et al. 2011; GonzálezWangüemert et al. 2014; González-Wangüemert et al. 2016, 2018; González-Wangüemert and DomínguezGodino 2016). Turkey is the main Mediterranean country actively harvesting and exporting sea cucumbers to Asian countries, including H. mammata, H. polii, H. tubulosa and H. sanctori (Çakli et al. 2004; Aydin 2008; González-Wangüemert et al. 2014; González-Wangüemert et al. 2015, 2016, 2018).

Sea cucumbers inhabit several sea floor habitats from intertidal zones to deep trenches, and from polar to tropical areas (Purcell et al. 2016). Those animals are mainly benthic and most of the exploited species are bottom detritus-feeders, consuming debris, bacteria and diatoms mixed with sediments on the seabed (Bruckner 2006; Purcell 2010; Purcell et al. 2016). Sea cucumbers have a low metabolism and its feeding source could influence their chemical composition, with strong implications for their nutritional properties (Aydin et al. 2011, Purcell et al. 2012, Yu et al. 2015). In this sense, this work makes a comparative evaluation of the chemical properties, including proximate composition, amino acids, fatty acids and essential and toxic metal contents of three commercial sea cucumber species (H. mammata, H. polii and H. tubulosa) caught from different locations of the Mediterranean Sea (SE Spain). Whenever possible results were compared with those obtained from the literature for the same species, caught from other Mediterranean areas such as Turkey and Italy. The amino acid levels of H. mammata is herein reported for the first time. Data was discussed through ecological and nutraceutical perspectives.

\section{Materials and methods}

Sample collection, processing and genetic identification

Holothuria mammata and $H$. tubulosa were collected in Los Cocedores (Murcia, SE Spain) while H. polii was caught in Los Urrutias (Mar Menor coastal lagoon, Murcia, SE Spain) (Fig. 1). All species were sampled during April of 2012 by scuba diving at 5 meters depth. Ten individuals of each target species were caught for analysis.

$H$. individuals had an average length of $19.32 \pm 4.62 \mathrm{~cm}$ being located into rock crevice close to Posidonia oceanica meadows. Holothuria tubulosa specimens showing an average length of $24.71 \pm 3.10 \mathrm{~cm}$ were caught on sandy and muddy bottom. Holothuria polii individuals with an average length of $14.02 \pm 2.24 \mathrm{~cm}$ were sampled from Mar Menor coastal lagoon close to Caulerpa prolifera and Cymodocea nodosa meadows. This species is showing individuals with lower size than populations outside coastal lagoon (GonzálezWangüemert personal observation). Sea cucumbers were identified in situ considering its external morphology. Later this identification was confirmed using traditional taxonomic characters, such as ossicles, on the basis of the original descriptions of these species (Gmelin 1791; Grube 1840; Delle Chiaje 1824) and other relevant taxonomic contributions (Borrero-Pérez et al. 2009, 2010). This identification was further confirmed using genetic barcoding, by amplifying the cytochrome c oxidase I (COI) gene according to protocol from González-Wangüemert and Borrero-Pérez (2012). PCR fragments were sequenced and Basic Local Alignment 


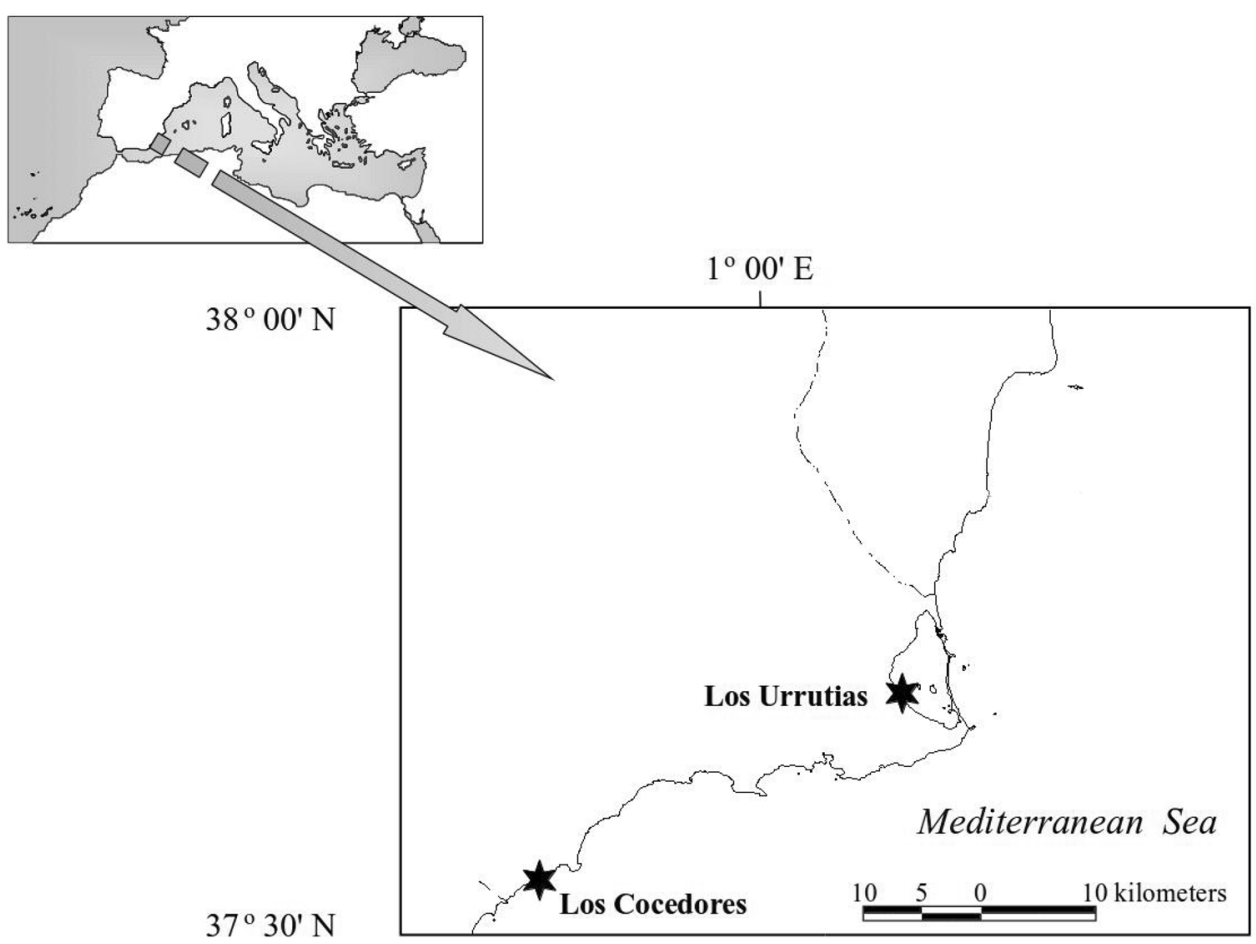

Fig. 1 Sampling sites of H. mammata and H. tubulosa (Los Cocedores/Almeria, Spain) and H. polii (Los Urrutias-Mar Menor coastal lagoon/Murcia, Spain)

Search Toll (BLAST) was performed against GenBank nucleotide database (www.ncbi.nlm.nih.gov/genbank). BLAST finds regions of local similarity between sequences and calculates statistical significance of matches. BLAST can be used to infer functional and evolutionary relationships between sequences as well as help identify members of gene families.

For the biochemical analysis fresh adult individuals were gutted, all inner organs were removed and the body walls were rinsed with fresh water. Samples were frozen at $-20{ }^{\circ} \mathrm{C}$, freeze-dried, ground into a fine powder, pooled and stored at $-20^{\circ} \mathrm{C}$ in tightly closed plastic bags until analyses. Each sample corresponded to ten adult individuals.

Biochemical analysis

Biochemical analysis included the determination of proximate composition, amino acids, fatty acid methyl esters (FAME) and minerals contents. These parameters were determined according to methods widely used to ascertain the biochemical profile of edible marine organisms in general (Njinkoue et al. 2016; Lah et al. 2017), and sea cucumber species in particular (Çakli et al. 2004; Zhong et al. 2007; Wen et al. 2010; Aydin et al. 2011; Roggatz et al. 2016; Gao et al. 2016).

Proximate composition

Moisture was determined by drying the samples at $52{ }^{\circ} \mathrm{C}\left( \pm 1{ }^{\circ} \mathrm{C}\right)$ until a constant weight was obtained (5 days). Ash was determined by incineration in a muffle furnace at $525^{\circ} \mathrm{C}$ until the samples burned completely (5 h, AOAC 1990; Gressler et al. 2010) and the crude protein content $(N \times 6.25)$ was estimated by the macro-Kjeldahl method. For this method approximately $1 \mathrm{~g}$ of dried samples were digested using a catalyst mixture (1 pellet of kjeldahl catalyst $0.3 \%$ in $\mathrm{CuSO}_{4}-5 \mathrm{H}_{2} \mathrm{O}$ ) and $25 \mathrm{~mL}$ of concentrated sulfuric acid in a digestion apparatus (BICASA Minerox MOD BE 97) under increasing temperature (200-400 $\left.{ }^{\circ} \mathrm{C}\right)$ to convert all nitrogen forms present in the samples into ammonium sulfate. Sodium hydroxide (35\% solution) was then added to liberate the ammonia. The samples were distilled (P Selecta PRO-NITRO II) into $250 \mathrm{~mL}$ - 
Erlenmeyer flasks containing $10 \mathrm{~mL}$ of boric acid (4\% solution) and a bromocresol green indicator. The amount of nitrogen $(\% N)$ in the sample (corresponding to the amount of fixed ammonia), was determined by titration with $0.5 \mathrm{~N} \mathrm{HCL}$ according to the following formula:

$$
\% N=\frac{V_{\mathrm{HCL}} \times f_{\mathrm{HCL}} \times 0.014 \times 100}{P_{\text {sample }}}
$$

where $V_{\mathrm{HCL}}$ is the volume of hydrogen chloride needed for the neutralization $(\mathrm{mL}), f_{\mathrm{HCL}}$ the molarity of $\mathrm{HCl}$ used $\left(\mathrm{mol} \mathrm{L}^{-1}\right)$ and $P_{\text {sample }}$ is the exact weight of biomass $(\mathrm{g})$ used for the analysis. The protein content was calculated by multiplying by 6.25 , corresponding to approximately $16 \%$ of nitrogen content in proteins.

Crude fat was determined by a modified method of Bligh and Dyer (Pereira et al. 2013). In brief, a solution containing methanol, chloroform and water (2:2:1) was mixed with $100 \mathrm{mg}$ of dried biomass and homogenised with an IKA Ultra-Turrax disperser. Then, samples were centrifuged and a known volume of the organic phase was moved into pre-weighed tubes. The solvent was then evaporated in a gentle nitrogen flow and the tubes were reweighed to calculate the lipid content. Special care was taken to obtain a full homogenization and performing repeated washings and extractions, having in mind that sea cucumbers generally have a low lipid content. Results are expressed as g per $100 \mathrm{~g}$ of wet weight biomass (WW) and dry weight biomass (DW).

Amino acids

Total amino acids were determined by gas chromatography/mass spectrometry (GC/MS) after sample derivatization with $N$-methyl- $N$-tert-butyldimethylsilyltrifluoroacetamide (BSTFA) and trimethylchlorosilane (TMCS) according to Deng et al. (2005). In brief, dried samples $(100 \mathrm{mg}$ ) and the internal standard (Lnorvaline, $20 \mathrm{mg}$ ) were mixed with $500 \mu \mathrm{L}$ of acetonitrile and $500 \mu \mathrm{L}$ of MBSTFA + TMCS (99:1, v/v) in screw vials under microwave irradiation $(750 \mathrm{~W}, 60 \mathrm{~s})$. After cooling to room temperature, samples $(1 \mu \mathrm{L})$ were injected at $260{ }^{\circ} \mathrm{C}$ on an Agilent GC-MS, with a temperature profile of $50{ }^{\circ} \mathrm{C}(1 \mathrm{~min})$ and $10{ }^{\circ} \mathrm{C} \mathrm{min}{ }^{-1}$ to $300{ }^{\circ} \mathrm{C}(6 \mathrm{~min})$. To identify and quantify the amino acids, the total ion mode was used. A set of standards of four different concentrations containing all 22 proteinogenic amino acids was prepared and measured, and calibration curves were generated for each amino acid. Results are expressed as percentage of total amino acid content.

Fatty acid methyl esters (FAME) profile

The FAME content was determined by a modified protocol from Lepage and Roy (1984), as described previously (Pereira et al. 2013). In short, aliquots of dried samples (100 mg) were mixed with acetyl chloride and methanol (20:1, v/v) in reaction vessels and homogenized with an IKA Ultra-Turrax disperser for 2 min. Then, $1 \mathrm{~mL}$ of hexane was added to the mixture and heated $\left(100{ }^{\circ} \mathrm{C}, 1 \mathrm{~h}\right)$. One $\mathrm{mL}$ of distilled water was added to the mixture, followed by centrifugation and removal of the organic phase, which was dried with anhydrous sodium sulphate. Samples were finally injected in a Varian 450-GC/240-MS (Varian 450-Gas Chromatograph/240-MS IT Mass Spectrometer, Varian Inc., Palo Alto, CA, USA), equipped with a BR-5MS capillary column $(30 \mathrm{~m} \times 0.25 \mathrm{~mm}$ internal diameter, $0.25 \mu \mathrm{M}$ film thickness, Bruker). The injection temperature was $300{ }^{\circ} \mathrm{C}$, and the trap, manifold and transfer line were established to 22,50 and $250{ }^{\circ} \mathrm{C}$, respectively. Helium was used as the carrier and the temperature program for the $\mathrm{GC}$ oven was $60{ }^{\circ} \mathrm{C}(1 \mathrm{~min})$, $30{ }^{\circ} \mathrm{C} \mathrm{min}-1$ to $120{ }^{\circ} \mathrm{C}, 4{ }^{\circ} \mathrm{C} \min ^{-1}$ to $250{ }^{\circ} \mathrm{C}, 20{ }^{\circ} \mathrm{C} \mathrm{min}^{-1}$ to $270{ }^{\circ} \mathrm{C}$, and $2.5^{\circ} \mathrm{C} \mathrm{min}^{-1}$ to $300{ }^{\circ} \mathrm{C}$. For identification and quantification of the FAME total ion mode was used. Because of differences in the response factors, for each FAME separate calibration curves were determined in triplicate, using the Supelco ${ }^{\circledR} 37$ Component FAME Mix (Sigma-Aldrich, Sintra, Portugal) commercial standard. Values were expressed in amount $(\mu \mathrm{g} / \mathrm{g})$ of dry biomass. 
Minerals

Minerals were analysed by atomic absorption spectrometry-AAS (GBC Avanta Sigma, Australia) provided with a deuterium background correction. $\mathrm{Mg}, \mathrm{Na}, \mathrm{K}, \mathrm{Ca}, \mathrm{Fe}, \mathrm{Mn}$ and $\mathrm{Zn}$ were analysed by flame (F) AAS with an air-acetylene flame. $\mathrm{Cd}, \mathrm{Cr}, \mathrm{Ni}$ and $\mathrm{Pb}$ were analysed with electrothermal atomisation (ET) (GBC graphite furnace 3000) using an auto-sampler (PAL 3000) (Roggatz et al. 2016). The accuracy of the analytical procedure was assessed by the analysis of certified reference material, using Community Bureau of Reference BCR60 (Lagarosiphon major). Procedural blanks always accounted for less than $1 \%$ of the metal concentrations in samples. Values were expressed as $\mathrm{g} / \mathrm{kg}$ dry biomass ( $\mathrm{Ca}, \mathrm{Mg}, \mathrm{Na}$ and $\mathrm{K}$ ) or $\mathrm{mg} / \mathrm{kg}$ dry biomass (Fe, $\mathrm{Mn}, \mathrm{Zn}, \mathrm{Cr}, \mathrm{Pb}, \mathrm{Ni}$ and $\mathrm{Cd})$.

\section{Statistical analysis}

Results were expressed as mean \pm standard error of the mean (SEM). Significant differences were assessed by analysis of variance (ANOVA) or by Student-Newman-Keuls post hoc test $(p<0.05)$ (software "R", R Development Core Team 2013) with the packages GAD (Sandrini-Neto and Camargo 2011) and CAR (Fox and Weisberg 2011). For each species, three samples were analysed and the assays were carried out at least in triplicate.

\section{Results}

Morphological and genetic identification

Holothuria polii showed relative small buttons (ossicles) comparing with the other two species. Holothuria polii has buttons more rounded, with smooth surface and edged never wrinkled. Holothuria tubulosa shows buttons more slender with the surface an edges clearly wrinkled. Holothuria mammata was distinguished from H. tubulosa by its buttons, which are more elongated and slightly bigger.

COI gene amplification of the specimen caught in Los Urrutias (Mar Menor, SE Spain) allowed us to obtain a sequence of $484 \mathrm{bp}$ in length. The BLAST in GENBANK, identified the individual from Los Urrutias as $H$. polii with a $100 \%$ maximum identity (100\% query cover) with a specimen caught in Mar Menor (SE, Spain; EU750797) and 99\% maximum identity (100\% query cover) with a specimen sampled in Cabo de Palos (SE, Spain; GQ214758), but showing one mutational change in the 396 position. The haplotype for this specimen was recorded as EU750793. In the case of the individual found in Los Cocedores (Murcia, SE Spain) and identified as H. tubulosa using external morphology, the COI amplification (532 bp) and BLAST corroborated that identification, with a $99 \%$ maximum identity (100\% query cover) with a specimen from Murcia (SE Spain; GQ214750) showing three mutational changes in 260, 452 and 521 positions; the haplotype from this specimen is GQ214748. Finally, the specimen identified as H. mammata (external morphology) also sampled in Los Cocedores, was assigned rightly to the H. mammata individual GQ214747 sampled in Murcia (SE Spain), showing $99 \%$ maximum identity (100\% query cover) with only 3 mutational changes in the 12 , 152 and 194 positions; this haplotype was recorded as GQ214746.

\section{Proximate composition}

Proximate composition of the three sea cucumbers species is shown in Table 1 , and is expressed as $\%$ of total wet biomass (WW) and dry biomass (DW). Moisture ranged from $73.6 \%$ in $\mathrm{H}$. mammata to $81.2 \%$ in $\mathrm{H}$. tubulosa, and the crude ash content varied from $9.61 \%$ in $\mathrm{H}$. mammata to $14.7 \%$ in $\mathrm{H}$. tubulosa. In general all species had a low fat content, from $0.21 \%$ in $H$. tubulosa to $0.55 \%$ in H. mammata, and high protein levels, ranging from $3.01 \%$ in $H$. tubulosa to $11.1 \%$ in $H$. mammata. Holothuria polii showed intermediate values between the other two species, for all considered variables. All the species had adequate protein/lipid ratios (H. mammata, 20:1; H. polii, 23:1; H. tubulosa, 14:1). 
Table 1 Proximate composition of the body wall of H. mammata, H. polii and H. tubulosa

\begin{tabular}{|c|c|c|c|c|c|c|}
\hline & \multicolumn{2}{|l|}{ H. mammata } & \multicolumn{2}{|l|}{ H. polii } & \multicolumn{2}{|l|}{ H. tubulosa } \\
\hline & WW & DW & WW & DW & WW & DW \\
\hline Moisture $^{1}$ & $73.6 \pm 1.73^{\mathrm{b}}$ & - & $76.3 \pm 1.52^{\mathrm{b}}$ & - & $81.2 \pm 1.55^{\mathrm{a}}$ & - \\
\hline $\mathrm{Ash}^{2}$ & $9.61 \pm 0.32^{\mathrm{b}}$ & $34.4 \pm 1.21^{\mathrm{c}}$ & $13.4 \pm 0.43^{\mathrm{a}}$ & $56.54 \pm 1.81^{\mathrm{b}}$ & $14.7 \pm 0.34^{\mathrm{a}}$ & $78.1 \pm 1.80^{\mathrm{a}}$ \\
\hline Protein $^{2}$ & $11.1 \pm 0.27^{\mathrm{a}}$ & $42.0 \pm 1.02^{\mathrm{a}}$ & $7.37 \pm 0.24^{\mathrm{b}}$ & $31.09 \pm 1.01^{\mathrm{b}}$ & $3.01 \pm 0.23^{\mathrm{c}}$ & $16.0 \pm 1.11^{\mathrm{c}}$ \\
\hline $\mathrm{Fat}^{2}$ & $0.55 \pm 0.05^{\mathrm{a}}$ & $2.08 \pm 0.18^{\mathrm{a}}$ & $0.32 \pm 0.03^{\mathrm{b}}$ & $1.35 \pm 0.12^{\mathrm{b}}$ & $0.21 \pm 0.04^{\mathrm{b}}$ & $1.11 \pm 0.21^{\mathrm{b}}$ \\
\hline
\end{tabular}

Data represent the mean $\pm \mathrm{SD}(n=3)$

In the same row values followed by different letters are significantly different at $p<0.05$ (one-way ANOVA with StudentNewman-Keuls post hoc test)

${ }^{1}$ Percentage (\%)

${ }^{2} \mathrm{~g} / 100 \mathrm{~g}$ of wet weight (WW) and dry weight (DW)

Amino acids profile

The composition of total amino acids of dried sea cucumber is shown in Table 2, and results are given in \% of total amino acid content. Nineteen amino acids were detected, including 8 essential (EAA) and 11 non-

Table 2 Amino acid profile of H. mammata, H. polii and H. tubulosa in \% of total amino acid content

\begin{tabular}{|c|c|c|c|}
\hline & H. mammata & H. polii & H. tubulosa \\
\hline ALA & $12.2 \pm 0.3^{\mathrm{a}}$ & $15.1 \pm 2.6^{\mathrm{a}}$ & $14.5 \pm 2.7^{\mathrm{a}}$ \\
\hline ARG & $6.8 \pm 0.2^{\mathrm{d}}$ & $13.4 \pm 2.4^{\mathrm{a}}$ & $12.9 \pm 1.7^{\mathrm{b}}$ \\
\hline ASN & $1.0 \pm 0.2^{\mathrm{a}}$ & nd & nd \\
\hline ASP & $5.3 \pm 0.8^{\mathrm{a}}$ & $4.5 \pm 0.4^{\mathrm{b}}$ & $4.8 \pm 0.7^{\mathrm{b}}$ \\
\hline CYS & $8.2 \pm 2.9^{\mathrm{a}}$ & $2.4 \pm 0.8^{\mathrm{b}}$ & $2.4 \pm 0.9^{\mathrm{b}}$ \\
\hline GLU & $12.1 \pm 1.9^{\mathrm{ab}}$ & $8.4 \pm 1.4^{\mathrm{b}}$ & $8.6 \pm 2.1^{\mathrm{b}}$ \\
\hline GLN & $2.3 \pm 0.7^{\mathrm{b}}$ & $1.0 \pm 0.2^{\mathrm{b}}$ & $1.3 \pm 0.8^{\mathrm{b}}$ \\
\hline GLY & $11.8 \pm 0.6^{\mathrm{a}}$ & $10.6 \pm 1.2^{\mathrm{a}}$ & $10.6 \pm 1.1^{\mathrm{a}}$ \\
\hline PRO & $8.2 \pm 0.4^{\mathrm{a}}$ & $10.1 \pm 2.4^{\mathrm{a}}$ & $9.5 \pm 2.0^{\mathrm{a}}$ \\
\hline SER & $3.2 \pm 0.3^{\mathrm{b}}$ & $3.0 \pm 0.5^{\mathrm{b}}$ & $3.5 \pm 0.7^{\mathrm{b}}$ \\
\hline TYR & $7.1 \pm 1.3^{\mathrm{a}}$ & $3.8 \pm 1.4^{\mathrm{b}}$ & $3.3 \pm 1.4^{\mathrm{b}}$ \\
\hline Non-essential (NEAA) & $78.5 \pm 9.7^{\mathrm{a}}$ & $72.6 \pm 13.0^{\mathrm{a}}$ & $71.9 \pm 14.1^{\mathrm{a}}$ \\
\hline HIS & $2.0 \pm 0.6^{\mathrm{b}}$ & nd & nd \\
\hline ILE & $2.0 \pm 0.1^{\mathrm{b}}$ & $2.9 \pm 0.1^{\mathrm{a}}$ & $3.3 \pm 0.3^{\mathrm{a}}$ \\
\hline LEU & $3.7 \pm 0.1^{\mathrm{c}}$ & $5.4 \pm 0.4^{\mathrm{b}}$ & $5.8 \pm 0.6^{\mathrm{b}}$ \\
\hline LYS & $2.2 \pm 0.7^{\mathrm{b}}$ & $1.1 \pm 0.2^{\mathrm{b}}$ & $1.6 \pm 0.7^{\mathrm{b}}$ \\
\hline MET & $1.0 \pm 0.0^{\mathrm{b}}$ & $0.7 \pm 0.3^{\mathrm{b}}$ & $0.1 \pm 0.1^{\mathrm{d}}$ \\
\hline PHE & $3.3 \pm 2.0^{\mathrm{b}}$ & $8.1 \pm 1.5^{\mathrm{a}}$ & $7.9 \pm 2.3^{\mathrm{a}}$ \\
\hline THR & $3.3 \pm 0.1^{\mathrm{a}}$ & $3.4 \pm 0.6^{\mathrm{a}}$ & $3.7 \pm 0.7^{\mathrm{a}}$ \\
\hline VAL & $3.7 \pm 0.1^{\mathrm{b}}$ & $5.4 \pm 0.6^{\mathrm{a}}$ & $5.5 \pm 0.7^{\mathrm{a}}$ \\
\hline Essential (EAA) & $21.4 \pm 3.6^{\mathrm{a}}$ & $27.3 \pm 3.6^{\mathrm{a}}$ & $28.0 \pm 5.5^{\mathrm{a}}$ \\
\hline EAA/NEAA & 0.27 & 0.38 & 0.39 \\
\hline LYS/ARG & 0.33 & 0.09 & 0.12 \\
\hline
\end{tabular}

Data represent the mean $\pm \mathrm{SD}(n=2)$

nd not detected, $A L A$ alanine, $A R G$ arginine, $A S N$ asparagine, $A S P$ aspartic acid, $C Y S$ cysteine, $G L N$ glutamine, $G L U$ glutamic acid, GLY glycine, HIS histidine, ILE isoleucine, LEU leucine, LYS lysine, MET methionine, PHE phenylalanine, PRO proline, $S E R$ serine, THR threonine, TRP tryptophan, TYR tyrosine, VAL valine, TAA total amino acids, EAA essential amino acids, NEAA non-essential amino acids, $n d$ not detected

In the same row, values followed by different letters are significantly different at $p<0.05$ (one-way ANOVA with StudentNewman-Keuls post hoc test) 
essential amino acids (NEAA). The most abundant amino acids were alanine, arginine, glutamic acid, and glycine. All species had similar contents of EAA (21.4-28\%), and as a consequence, similar ratios of EAA/ NEAA. The lysine/arginine ratios ranged from 0.09 in $\mathrm{H}$. polii to 0.33 in H. mammata.

FA content and profile

The FA contents of the three sea cucumber species included in this work are represented in Table 3. They had high amounts of polyunsaturated FA (PUFA) ranging from $402 \mu \mathrm{g} / \mathrm{g}$ in $\mathrm{H}$. polii to $1028 \mu \mathrm{g} / \mathrm{g}$ in H. mammata. PUFA accounted for $32-42 \%$ of total FA content. The least concentrated FA in these species was the SFA $(321-526 \mu \mathrm{g} / \mathrm{g}$ ) which accounted for $21-27 \%$ of total FA. Arachidonic acid (AA, C20:4n-6) was the most abundant $\mathrm{FA}$ in $H$. mammata $(643 \mu \mathrm{g} / \mathrm{g})$ and $H$. tubulosa $(365 \mu \mathrm{g} / \mathrm{g})$, while oleic acid $(\mathrm{C} 18: 1 n-9 c)$ was predominant in H. polii $(246 \mu \mathrm{g} / \mathrm{g})$. All species had similar amounts of EPA $(115-221 \mu \mathrm{g} / \mathrm{g})$. In contrast, regarding docosahexaenoic acid (DHA, C22:6n-3) H. mammata $(89.7 \mu \mathrm{g} / \mathrm{g}$ ) and H. tubulosa $(63.7 \mu \mathrm{g} / \mathrm{g}$ ) had the highest contents. Besides palmitic acid (C16:0), and the two monounsaturated FA (MUFA) eicosenoic $(\mathrm{C} 20: 1 n-9)$ and nervonic acids (C24:1n-9), the other FA contributed to less than 5\% of the total amount of FA.

Table 3 FAME profile ( $\mu \mathrm{g} / \mathrm{g} \mathrm{DW})$ of H. mammata, H. polii and H. tubulosa

\begin{tabular}{|c|c|c|c|c|}
\hline & Common name & H. mammata & H. polii & H. tubulosa \\
\hline $\mathrm{C} 14: 0$ & Myristic acid & $45.5 \pm 1.7^{\mathrm{a}}$ & $31.3 \pm 6.5^{\mathrm{b}}$ & $47.5 \pm 1.5^{\mathrm{a}}$ \\
\hline C15:0 & Pentadecanoic acid & $21.3 \pm 0.7^{\mathrm{a}}$ & $10.0 \pm 1.1^{\mathrm{c}}$ & $19.7 \pm 1.7^{\mathrm{b}}$ \\
\hline C16:0 & Palmitic acid & $107 \pm 4^{\mathrm{a}}$ & $40.9 \pm 9.2^{\mathrm{c}}$ & $91.9 \pm 11.3^{b}$ \\
\hline $\mathrm{C} 17: 0$ & Margaric acid & $25.3 \pm 2.0^{\mathrm{a}}$ & $14.6 \pm 2.9^{\mathrm{b}}$ & $24.8 \pm 3.4^{\mathrm{a}}$ \\
\hline C18:0 & Stearic acid & $88.7 \pm 9.6^{\mathrm{a}}$ & $39.9 \pm 8.5^{\mathrm{c}}$ & $73.1 \pm 6.5^{\mathrm{b}}$ \\
\hline C19:0 & Nonadecanoic acid & $45.9 \pm 3.8^{\mathrm{a}}$ & $27.7 \pm 4.2^{\mathrm{b}}$ & $39.2 \pm 3.2^{\mathrm{b}}$ \\
\hline C20:0 & Arachidic acid & $67.9 \pm 4.3^{\mathrm{a}}$ & $42.0 \pm 6.9^{b}$ & $51.2 \pm 1.8^{\mathrm{a}}$ \\
\hline $\mathrm{C} 21: 0$ & Heneicosanoic acid & $61.9 \pm 5.4^{\mathrm{a}}$ & $35.9 \pm 7.8^{\mathrm{b}}$ & $41.5 \pm 4.0^{\mathrm{c}}$ \\
\hline $\mathrm{C} 22: 0$ & Behenic acid & nd & $37.4 \pm 7.0^{\mathrm{b}}$ & $42.8 \pm 3.3^{\mathrm{a}}$ \\
\hline C23:0 & Tricosanoicc acid & $27.5 \pm 2.7^{b}$ & $16.9 \pm 5.0^{\mathrm{a}}$ & $18.9 \pm 2.6^{b}$ \\
\hline $\mathrm{C} 24: 0$ & Lignoceric acid & $34.9 \pm 7.9^{\mathrm{b}}$ & $24.8 \pm 1.7^{\mathrm{a}}$ & $27.7 \pm 0.9^{\mathrm{b}}$ \\
\hline$\Sigma$ SFA & & $526 \pm 35^{\mathrm{a}}$ & $321 \pm 17^{\mathrm{c}}$ & $478 \pm 29^{\mathrm{b}}$ \\
\hline C16:1 & Palmitoleic acid & $76.0 \pm 3.1^{b}$ & $23.5 \pm 7.3^{\mathrm{c}}$ & $60.1 \pm 6.8^{\mathrm{ab}}$ \\
\hline C18:1n-9 c & Oleic acid & $350 \pm 23^{\mathrm{c}}$ & $246 \pm 32^{\mathrm{a}}$ & $288 \pm 18^{\mathrm{b}}$ \\
\hline C18:1n-9 t & Elaidic acid & $58.9 \pm 5.9^{\mathrm{b}}$ & $24.1 \pm 5.2^{\mathrm{c}}$ & $49.1 \pm 6.6^{\mathrm{a}}$ \\
\hline C20:1n-9 & Eicosenoic acid & $137 \pm 12^{\mathrm{b}}$ & $90.1 \pm 18.3^{\mathrm{a}}$ & $91.2 \pm 14.6^{\mathrm{c}}$ \\
\hline C22:1n-9 & Docosenoic acid & $67.0 \pm 6.3^{b}$ & $44.1 \pm 7.0^{\mathrm{a}}$ & $43.0 \pm 4.8^{\mathrm{c}}$ \\
\hline C24:1n-9 & Nervonic acid & $182 \pm 19^{\mathrm{a}}$ & $85.6 \pm 17.4^{\mathrm{b}}$ & $99.1 \pm 10.9^{c}$ \\
\hline$\Sigma$ MUFA & & $870 \pm 113^{b}$ & $514 \pm 79^{\mathrm{a}}$ & $631 \pm 90^{\mathrm{b}}$ \\
\hline C18:2n-6 & Linoleic acid & $35.8 \pm 3.4^{\mathrm{a}}$ & $16.1 \pm 1.8^{\mathrm{b}}$ & $27.3 \pm 1.5^{\mathrm{a}}$ \\
\hline C20:4n-6 & Arachidonic acid (AA) & $643 \pm 85^{\mathrm{a}}$ & $228 \pm 54^{\mathrm{c}}$ & $365 \pm 46^{\mathrm{b}}$ \\
\hline$C 20: 5 n-3$ & Eicosapentaenoic acid (EPA) & $221 \pm 31^{\mathrm{a}}$ & $115 \pm 27^{\mathrm{a}}$ & $157 \pm 19^{\mathrm{a}}$ \\
\hline C20:2n-6 & Eicosadienoic acid & $38.2 \pm 3.3^{\mathrm{a}}$ & $16.3 \pm 1.8^{\mathrm{b}}$ & $30.4 \pm 3.6^{\mathrm{a}}$ \\
\hline$C 22: 6 n-3$ & Docosahexaenoic acid (DHA) & $89.7 \pm 9.5^{\mathrm{a}}$ & $26.1 \pm 4.3^{b}$ & $63.7 \pm 6.4^{\mathrm{a}}$ \\
\hline$\Sigma$ PUFA & & $1028 \pm 202^{\mathrm{a}}$ & $402 \pm 75^{\mathrm{b}}$ & $643 \pm 116^{\mathrm{ab}}$ \\
\hline$\sum n-3$ & & $311 \pm 32^{\mathrm{a}}$ & $141 \pm 27^{\mathrm{b}}$ & $220 \pm 20^{\mathrm{a}}$ \\
\hline$\sum n-6$ & & $717 \pm 85^{\mathrm{a}}$ & $260 \pm 54^{\mathrm{c}}$ & $422 \pm 46^{\mathrm{b}}$ \\
\hline$\sum n-6 / n-3$ & & 2.3 & 1.8 & 1.9 \\
\hline
\end{tabular}

Data represent the mean $\pm \mathrm{SD}(n=3)$

$\Sigma S F A$ total saturated fatty acids (FAs), $\Sigma M U F A$ total monounsaturated FAs, $\Sigma P U F A$ total polyunsaturated FAs, $\Sigma n-3$ total omega-3 PUFAs; $\Sigma n-6$ total omega-6 PUFAs; $\Sigma n-6 / n-3$ ratio of omega- 6 to omega-3 fatty acids, $n d$ not detected

In the same row, values followed by different letters are significantly different at $p<0.05$ (one-way ANOVA with StudentNewman-Keuls post hoc test) 
The amount of $\Sigma n$-6 FAME (260-717 $\mu \mathrm{g} / \mathrm{g})$ was always higher than the percentage of $\Sigma n$-3 (141-311 $\mu \mathrm{g} / \mathrm{g})$ in all species. The ratio between the $\Sigma n-6$ and $\Sigma n-3(1.8-2.3)$ was similar for the three species.

Minerals

As shown in Table 4, the sea cucumbers under study contain many dietary essential minerals, such as sodium $(56.9-75.2 \mathrm{~g} / \mathrm{kg}$ ), potassium $(3.37-5.58 \mathrm{~g} / \mathrm{kg}$ ), calcium (41.1-145 g/kg), magnesium $(12.7-21.4 \mathrm{~g} / \mathrm{kg})$, iron $(33.7-4400 \mathrm{~g} / \mathrm{kg})$, zinc $(8.9-227.7 \mathrm{mg} / \mathrm{kg})$, and manganese $(4.53-86.6 \mathrm{mg} / \mathrm{kg})$. Holothuria polii had the highest levels of calcium $(145 \mathrm{~g} / \mathrm{kg})$ and magnesium $(21.4 \mathrm{~g} / \mathrm{kg})$, while $H$. tubulosa had the highest content of residual metals; especially iron $(4400 \mathrm{mg} / \mathrm{kg})$, which was 100 times higher than the amounts found in the remaining species. A similar trend was observed with the other residual minerals such as manganese and zinc and also with the toxic metals chromium, lead and nickel (Table 4).

\section{Discussion}

The proximate composition of fresh sea cucumbers differs between species, catching season and feeding patterns (Bordbar et al. 2011). Holothurians are on the bottom of the food chain and help to recycle detritus, since most of them are deposit feeders that consume bacteria and diatoms mixed with sediments on the seabed (Purcell 2010; Purcell et al. 2016). Bacterial densities in sediments can differ greatly from site to site being generally associated with the type of organic compounds found in those sediments. For example, significant differences in chlorophyll $a$ concentration and bacterial cell concentrations were observed between the Eastern and Western Mediterranean sediments and water, associated with a shift from carbohydrates to amino acids as the dominant biochemical components (Danovaro et al. 1999). Such diversity in feeding source could explain the variation in the chemical composition of sea cucumbers (Aydin et al. 2011).

The high-moisture levels registered in the sea cucumbers studied on this work are in accordance with the values found in the literature for the same species sampled in the Eastern Mediterranean regions (Aydin et al. 2011), and in the Southern Adriatic Sea (Sicuro et al. 2012), and also for other sea cucumber species belonging to the same genus and inhabiting the SW Mediterranean region, as for example, H. arguinensis (Roggatz et al. 2016). The crude ash contents was higher than the values reported by other authors in the same species from Turkey (Çakli et al. 2004; Aydin et al. 2011) and from the Southern Adriatic Sea (Sicuro et al. 2012), and also than those reported for important commercial sea cucumbers, such as Stichopus japonicus L. (Gao et al. 2016).

Table 4 Mineral content of the body wall of H. mammata, H. polii and H. tubulosa in $\mathrm{g} / \mathrm{kg}$ dry biomass $(\mathrm{Ca}, \mathrm{Mg}, \mathrm{Na}$ and $\mathrm{K})$ or $\mathrm{mg} / \mathrm{kg}$ dry biomass ( $\mathrm{Fe}, \mathrm{Mn}, \mathrm{Zn}, \mathrm{Cr}, \mathrm{Pb}, \mathrm{Ni}$ and $\mathrm{Cd}$ )

\begin{tabular}{lllll}
\hline & Symbol & H. mammata & H. polii & H. tubulosa \\
\hline Calcium & $\mathrm{Ca}$ & $41.1 \pm 0.05^{\mathrm{c}}$ & $145 \pm 0.13 \mathrm{a}$ & $95.8 \pm 0.86^{\mathrm{b}}$ \\
Magnesium & $\mathrm{Mg}$ & $12.7 \pm 0.04^{\mathrm{c}}$ & $21.4 \pm 0.10^{\mathrm{a}}$ & $16.6 \pm 0.09^{\mathrm{b}}$ \\
Sodium & $\mathrm{Na}$ & $66.5 \pm 0.45^{\mathrm{b}}$ & $56.9 \pm 0.38^{\mathrm{c}}$ & $75.2 \pm 1.01^{\mathrm{a}}$ \\
Potassium & $\mathrm{K}$ & $3.86 \pm 0.01^{\mathrm{b}}$ & $3.27 \pm 0.07^{\mathrm{b}}$ & $5.58 \pm 0.15^{\mathrm{a}}$ \\
Iron & $\mathrm{Fe}$ & $33.7 \pm 2.28^{\mathrm{c}}$ & $40.6 \pm 0.30^{\mathrm{b}}$ & $4400 \pm 77.94^{\mathrm{a}}$ \\
Manganese & $\mathrm{Mn}$ & $4.53 \pm 0.14^{\mathrm{c}}$ & $46.2 \pm 0.83^{\mathrm{b}}$ & $86.6 \pm 3.47^{\mathrm{a}}$ \\
Zinc & $\mathrm{Zn}$ & $10.5 \pm 0.08^{\mathrm{b}}$ & $8.90 \pm 0.04^{\mathrm{c}}$ & $227.7 \pm 0.48^{\mathrm{a}}$ \\
Chromium & $\mathrm{Cr}$ & $0.87 \pm 0.02^{\mathrm{b}}$ & $0.77 \pm 0.02^{\mathrm{b}}$ & $15.2 \pm 0.42^{\mathrm{a}}$ \\
Lead & $\mathrm{Pb}$ & $\mathrm{nd}$ & $3.07 \pm 0.02^{\mathrm{b}}$ & $6.5 \pm 0.07^{\mathrm{a}}$ \\
Nikel & $\mathrm{Ni}$ & $0.46 \pm 0.03^{\mathrm{b}}$ & $\mathrm{nd}$ & $2.5 \pm 0.07^{\mathrm{a}}$ \\
Cadmium & $\mathrm{Cd}$ & nd & $0.09 \pm 0.01^{\mathrm{a}}$ & $\mathrm{nd}$ \\
\hline
\end{tabular}

Data represent the mean $\pm \mathrm{SD}(n=3)$

$n d$ not detected

In the same row, values followed by different letters are significantly different at $p<0.05$ (one-way ANOVA with StudentNewman-Keuls post hoc test) 
These results could be related to higher levels of minerals in the tissues, which could be linked with the higher availability of diatoms and microalgae in this geographical area (SW Mediterranean Sea; Rohling et al. 2015), which are consumed by cucumbers.

Sea cucumbers are generally characterized by low amounts of fat and high protein contents (Bordbar et al. 2011). The protein levels of the sea cucumbers were high, although slightly lower than those reported in the literature for different sea cucumber species, as for example, Actinopyga mauritiana and Bohadschia argus (Wen et al. 2010). Holothuria tubulosa had a lower protein content than the same species caught in Turkey (Aydin et al. 2011) and in the Southern Adriatic Sea (Sicuro et al. 2012). Holothuria polii had a similar crude protein content that the same species caught in the later area (Sicuro et al. 2012). The sampling location had little effect on the protein levels of H. mammata. The species under study had a low crude fat content, but higher than the values reported for the same species caught in the Southern Adriatic Sea (Sicuro et al. 2012), and also than the reference amount reported for other commercial sea cucumber species (Bordbar et al. 2011). The fat contents was, however, lower than the values reported for other seafood products, namely skipjack tuna (Katsuwonus pelamis; Khodabux et al. 2007). All species had an appropriate protein/lipid ratio which is nutritionally relevant in view of the important role of proteins for the human body.

The amino acid profile of the studied species agrees with the reported in literature for the same species (Sicuro et al. 2012) and also for different sea cucumbers genera, such as Cucumaria and Actinopygia (Zhong et al. 2007; Wen et al. 2010). The richness of glycine is highly relevant, since the intake of food rich in that amino acid is associated with the reduction in total cholesterol levels in serum (Aljawad et al. 1991; Ikeda et al. 1993). The lysine/arginine ratios are usually linked to hypocholesterolemic effects (Bordbar et al. 2011) and were lower than those usually described in different sea cucumbers species (Bordbar et al. 2011).

All species showed a higher proportion of PUFA relatively to other FA, while SFA were present in the lowest relative amount. PUFA are significant components in tissue repair and wound healing, inflammation prevention, reduction of the incidence of coronary heart disease and cancer (Fredalina et al. 1999; Gill and Valivety 1997; Roynette et al. 2004; Harper and Jacobson 2005). AA was the most representative FA, as observed for most species of sea cucumbers (Bordbar et al. 2011). This FA is a major component of the cell membrane phospholipids and has a potential role in growth and in blood clotting process leading to wound healing (Gill and Valivety 1997; Roynette et al. 2004; Harper and Jacobson 2005; Harris et al. 2008). The levels of EPA and DHA together ranged from $141 \mu \mathrm{g} / \mathrm{g}$ in $\mathrm{H}$. polii to $311 \mu \mathrm{g} / \mathrm{g}$ in H. mammata. Both PUFAs are associated with several health benefits, from the prevention of cardiovascular diseases to the improvement of brain and eye function (Harris et al. 2008). The levels of such PUFA in these species are, however, very low considering the daily intake requirements advised by the WHO (around $500 \mathrm{mg} / \mathrm{d}$ of EPA + DHA). Nonetheless, the FA profile of these species, with $n-6$ to $n-3$ FA ratios (1.8-2.3) considerably lower than 10 is highly beneficial to human health (Sánchez-Machado et al. 2004; Schmitz and Ecker 2008). Hence, the consumption of these species is not likely to have an adverse effect on cardiovascular diseases.

When compared to previously reported studies, some significant differences can be deduced from the profiles obtained herein, probably due to the distinct geographical origins of the species used. The FA profile of $H$. polii, H. tubulosa and H. mammata reported by Aydin et al. (2011) for example, shows a similar FA pattern to our results in which AA and EPA are among the most abundant FA. However, contrary to our results, in that study, oleic acid was not a dominant FA and $\alpha$-linolenic (C18:3n-3) and eicosadienoic (C20:2) acids were also detected (Aydin et al. 2011). Our results were not comparable with those reported for $H$. tubulosa and $H$. polii caught from Italian Southern Adriatic Sea due to the different processing method used, which consisted in drying samples at $70{ }^{\circ} \mathrm{C}$ for $24 \mathrm{~h}$ prior to chemical analysis (Sicuro et al. 2012), since this drying method can modify the fatty acids contents of the samples (Bordbar et al. 2011).

Fatty acids have been increasingly used as biomarkers by ecologists to trace the origin and trajectory of organic matter in ecosystems (Parrish et al. 2000). According to Alfaro et al. (2006) long chain FA (with 24 or more carbons) are characteristic of terrestrial plants and thus their presence indicates organic material of terrestrial origin. On the other hand, the presence of EPA and DHA are indicative of diatoms and dinoflagellates, respectively, in the sea cucumbers food sources. As sea cucumbers are bottom feeders with low metabolism, it is probable that the FA composition of their body walls reflects the FA composition of their food source (Ramón et al. 2010; Aydin et al. 2011). In this context, species enriched in C24:0 FA would feed mainly on food sources of terrestrial origin, while those with prevalence of EPA and DHA would feed mainly on marine food sources. Holothuria polii was collected in a location more influenced by terrestrial inputs than 
the remaining species. In fact, $H$. polii was collected from Los Urrutias (SW Mar Menor coastal lagoon, SE Spain), a location close to several temporary and stable watercourses harbouring waters and sediments from agriculture and urban areas (González-Wangüemert and Vergara-Chen 2014). Holothuria mammata and H. tubulosa sampled from Los Cocedores (Murcia, Mediterranean Sea, SE Spain) presented a mixed signature, because of the terrestrial inputs in this marine region are limited and only produced during the rain season. In general, bacteria present a distinct lipid profile, usually enriched in SFA and MUFA, contrary to microalgae, which are showing high content in PUFA (Lebreton et al. 2011).

Sea cucumbers usually contain a good mineral profile, with high amounts of $\mathrm{Ca}, \mathrm{Mg}, \mathrm{Fe}$ and $\mathrm{Zn}$ (Bordbar et al. 2011). In this work, $H$. polii had the highest content of $\mathrm{Ca}, \mathrm{Mg}$ and $\mathrm{K}$, but the highest levels of $\mathrm{Fe}$ and $\mathrm{Zn}$ were observed in $H$. tubulosa (Table 4). The human consumption of ingredients rich in nutrients such as $\mathrm{K}$, $\mathrm{Ca}, \mathrm{Mg}, \mathrm{Fe}, \mathrm{Zn}$, and $\mathrm{Mn}$ can have positive health implications, since they are an essential part of many important enzymes and they play different roles as catalysts and antioxidants. Holothuria tubulosa had a very high content of these essential metals, but also the highest levels of toxic metals such as $\mathrm{Cr}, \mathrm{Pb}$ and $\mathrm{Ni}$. Holothuria tubulosa had higher amounts of $\mathrm{Cr}, \mathrm{Fe}, \mathrm{Pb}$ and $\mathrm{Zn}$ than the same species from Southern Adriatic Sea (Sicuro et al. 2012); while $\mathrm{H}$. polii had lower levels of $\mathrm{Fe}$ and $\mathrm{Zn}$, and a higher content of $\mathrm{Pb}$ (Sicuro et al. 2012). Working with the same species caught in the Northern Mediterranean Sea, Tunca et al. (2016) observed that $H$. mammata significantly accumulated some metals, such as $\mathrm{Cd}$ and $\mathrm{Mn}$ in its body wall, while $H$. polii accumulated $\mathrm{Cu}, \mathrm{Cd}, \mathrm{Cr}$ and $\mathrm{Mn}$ at the lowest amount. The levels of $\mathrm{Pb}$ found in our study for $H$. tubulosa are lower or similar than those reported for the same species caught in the NW Mediterranean (Warnau et al. 2006), while the $\mathrm{Fe}$ and $\mathrm{Zn}$ contents were much higher. The accumulation of minerals in living organisms is influenced by several factors, as for example, the environment, concentration and type of the mineral in the bottom, exposure time, presence of other elements in the environment, condition, metabolic rate and/or sex of the organism, physico-chemical characteristics of the medium and feeding habits (Warnau et al. 2006). The differences in the levels of particular minerals observed in our study can be ascribed, for example, to possible differences in feeding habits between species (Aydın 2008; Aydın and Erkan 2015). Previous works showed that the decomposition of plant tissues, including seagrass, may be a source of metals to the marine environment, which are released through leaching and mineralization, and sink after adsorption to litter (Weis and Weis 2004). The high metal contents in H. tubulosa tissues could, therefore, be partially explained by its feeding behaviour associated to sediment from seagrass meadows which are showing a potential high metal concentration (Marín-Guirao et al. 2005; Warnau et al. 2006). In fact, it has been suggested that due to the peculiar ecological characteristics of $H$. tubulosa, this species could be used to complement the small set of bioindicators available so far for surveying metal contamination in the Posidonia oceanica ecosystem from Mediterranean Sea (Warnau et al. 2006). Holothuria tubulosa was caught from Los Cocedores, a location with vast areas of $P$. oceanica and $C$. nodosa meadows; some authors have described the bio-accumulation of heavy metals on these marine phanerogam species (de Leon et al. 1982; Marín-Guirao et al. 2005). Holothuria tubulosa is usually associated with those meadows with $24 \mathrm{~h}$ feeding activity (Costa et al. 2014), while $H$. mammata is found during the day under the rocks, and only gets out at night for feeding in areas not close to $P$. oceanica (González-Wangüemert et al. 2016). Moreover, H. tubulosa could be a more efficient metal bioaccumulator than $H$. mammata (Warnau et al. 2006). Although 50\% lower than in $H$. tubulosa, the $\mathrm{Pb}$ concentration in $H$. polii was significantly lower than those quantified on the body wall tissues of sea cucumbers from the Southern Adriatic Sea (Storelli et al. 2001). Moreover, H. polii was the only species in which Cd was found in concentrations similar to those reported by other authors (Storelli et al. 2001). Holothuria polii was collected in the south basin of the Mar Menor lagoon, which is one of the largest coastal lagoons in Europe. Mar Menor has fresh-water inputs and its southern part is enclosed by mountains, which were subjected to intense mining activity in the last two centuries (Marín-Guirao et al. 2005). Although mining activity stopped in 1991, during flood seasons the metals of mine tailings, including $\mathrm{Pb}$ and $\mathrm{Cd}$, are released to Mar Menor and accumulate in the sediments and in the seagrass C. nodosa (de Leon et al. 1982; Marín-Guirao et al. 2005) which could explain the high levels of those elements detected on H. polii. 


\section{Conclusions}

All species had high moisture, ash and protein levels, low lipid content, and adequate amounts of most essential amino acids, coupled with low lysine to arginine ratios. The FA profiles of all species were characterized by high levels of omega-3 PUFA and considerable amounts of DHA and EPA. Holothuria polii had a FA profile enriched in C24:0 FA, while H. mammata and H. tubulosa had a prevalence of EPA and DHA. Holothuria tubulosa had a high content of toxic metals such as $\mathrm{Cr}, \mathrm{Pb}$ and $\mathrm{Ni}$. This work pinpoints the influence of some physical parameters of the environment, namely mineral loads and terrestrial inputs, on the nutritional properties of sea cucumbers.

Acknowledgements This work was supported by the CCMAR/Multi/04326/2013, SEABIOMED (PTDC/MAR/103957/2008), CUMFISH (PTDC/MAR/119363/2010) and CUMARSUR (PTDC/MAR-BIO/5948/2014) projects funded by the Foundation for Science and Technology (FCT) and the Portuguese National Budget. Luísa Custódio and Mercedes González-Wangüemert were supported by FCT Investigator Programme (IF/00049/2012 and IF/00998/2014, respectively). The authors acknowledge Dr. Zélia Velez (CCMAR) and Dr. Maribela Pestana (FCT) for their assistance with the analysis of amino acids and total proteins, respectively.

Open Access This article is distributed under the terms of the Creative Commons Attribution 4.0 International License (http:// creativecommons.org/licenses/by/4.0/), which permits unrestricted use, distribution, and reproduction in any medium, provided you give appropriate credit to the original author(s) and the source, provide a link to the Creative Commons license, and indicate if changes were made.

\section{References}

Alfaro AC, Thomas F, Sergent L, Duxbury M (2006) Identification of trophic interactions within an estuarine food web (northern New Zealand) using fatty acid biomarkers and stable isotopes. Estuar Coast Shelf Sci 70:271-286

Aljawad NS, Beth FE, Fryer HC (1991) Effects of casein, soy, and whey proteins and amino acid supplementation on cholesterol metabolism in rats. J Nutr Biochem 2:150-155

AOAC (1990) Official methods of analyses of association of analytical chemists, 15th edn. AOAC, Washington

Aydin M (2008) The commercial sea cucumber fishery in Turkey. SPC Bêche de Mer Bull 28:40-41

Aydin M, Erkan S (2015) Identification and some biological characteristics of commercial sea cucumber in the Turkey coast waters. Int J Fish Aquat Stud 3:260-265

Aydin M, Sevgili H, Tufan B, Emre Y, Köse S (2011) Proximate composition and fatty acid profile of three different fresh and dried commercial sea cucumbers from Turkey. Int J Food Sci Technol 46:500-508

Bordbar S, Anwar F, Saari N (2011) High-value components and bioactives from sea cucumbers for functional foods-a review. Mar Drugs 9:1761-1805

Borrero-Pérez G, Pérez-Ruzafa Á, Marcos C, González-Wangüemert M (2009) The taxonomic status of some AtlantoMediterranean species in the subgenus Holothuria (Echinodermata: Holothuroidea: Holothuriidae) based on molecular evidence. Zool J Linn Soc 157:51-69

Borrero-Pérez G, Gómez-Zurita J, González-Wangüemert M, Marcos C, Pérez-Ruzafa A (2010) Molecular systematic of the genus Holothuria in the Mediterranean and Northeastern Atlantic and a molecular clock for the diversification of the Holothuriidae (Echinodermata: Holothuroidea). Mol Phylogenet Evol 57:899-906

Bruckner AW (ed) (2006) Proceedings of the CITES workshop on the conservation of sea cucumbers in the families Holothuriidae and Stichopodidae. NOAA technical memorandum NMFS-OPR 34, Silver Spring

Çakli Ş, Cadun A, Kişla D, Dinçer T (2004) Determination of quality characteristics of Holothuria tubulosa, (Gmelin, 1788) in Turkish Sea (Aegean Region) depending on sun drying process step used in Turkey. J Aquat Food Prod Technol 13:69-78

Choo PS (2008) Population status, fisheries and trade of sea cucumbers in Asia. In: Toral-Granda V, Lovatelli A, Vasconcellos M (eds) Sea cucumbers: a global review of fisheries and trade. FAO fisheries and aquaculture technical paper no. 516. FAO, Rome, pp 81-118

Conand C, Byrne M (1993) A review of recent developments in the world sea cucumber fisheries. Mar Fish Rev 55:1-13

Conand C (2008) Population status, fisheries and trade of sea cucumbers in Africa and the Indian Ocean. In: Toral-Granda V, Lovatelli A, Vasconcellos M (eds) Sea cucumbers: a global review of fisheries and trade, vol 516. FAO fisheries and aquaculture technical paper no. 516. FAO, Rome, pp 143-193

Costa V, Mazzola A, Vizzini S (2014) Holothuria tubulosa Gmelin 1791 (Holothuroidea, Echinodermata) enhances organic matter recycling in Posidonia oceanica meadows. J Exp Mar Biol Ecol 461:226-232

Danovaro R, Dinet A, Duineveld G, Tselepides A (1999) Benthic response to particulate fluxes in different trophic environments: a comparison between the Gulf of Lions-Catalan Sea (western-Mediterranean) and the Cretan Sea (eastern-Mediterranean). Prog Oceanogr 44:287-312

de Leon AR, Guerrero J, Faraco F (1982) Evolution of the pollution of the coastal lagoon of Mar Menor. VI Journées Étud. Pollutions. CIESM, Cannes 
Deng C, Yin X, Zhang L, Zhang X (2005) Development of microwave-assisted derivatization followed by gas chromatography/mass spectrometry for fast determination of amino acids in neonatal blood samples. Rapid Commun Mass Spectrom 19:2227-2234

FAO (2011) Fisheries statistics. http://www.fao.org/fishery/statistics/en. Accessed 20 Dec 2017

FAO (2014) The state of world fisheries and aquaculture, Rome

Fox J, Weisberg S (2011) An $\{\mathrm{R}\}$ companion to applied regression, 2nd edn. Sage, Thousand Oaks. http://socserv.socsci. mcmaster.ca/jfox/Books/Companion. Retrieved 01 May 2012

Fredalina B, Ridzwan B, Abidin A, Kaswandi M, Zaiton H, Zali I, Kittakoop P, Jais A (1999) Fatty acid compositions in local sea cucumber: Stichopus chloronotus, for wound healing. Gen Pharmacol 33:337-340

Gao Y, Li Z, Qi Y, Guo Z, Lin Y, Li W, Hu Y, Qiancheng Zhao Q (2016) Proximate composition and nutritional quality of deep sea growth sea cucumbers (Stichopus japonicus) from different origins. J Sci Food Agric 96:2378-2383

Gill I, Valivety R (1997) Polyunsaturated fatty acids, part 1: occurrence, biological activities and applications. Trends Biotechnol 15:401-409

González-Wangüemert M, Borrero-Pérez G (2012) A new record of Holothuria arguinensis colonizing the Mediterranean Sea. Mar Biodivers Rec 5:e105

González-Wangüemert M, Domínguez-Godino JA (2016) Sea cucumbers as new marine resource in Europe. Front Mar Sci. https://doi.org/10.3389/conf.fmars.2016.04.00112

González-Wangüemert M, Vergara-Chen C (2014) Environmental variables, habitat discontinuity and life history shaping the genetic structure of Pomatoschistus marmoratus. Helgol Mar Res 68:357-371

González-Wangüemert M, Aydin M, Chantal C (2014) Assessment of target sea cucumber populations from Aegean Sea (Turkey): first insights for a right management of their fisheries. Ocean Coast Manag 92:87-94

González-Wangüemert M, Valente S, Aydin M (2015) Effects of fishery protection on biometry and genetic structure of two target sea cucumber species from the Mediterranean Sea. Hydrobiologia 743:65-74

González-Wangüemert M, Valente S, Henriques F, Domínguez-Godino J, Serrão E (2016) Setting preliminary biometric baselines for new target sea cucumbers species of the NE Atlantic and Mediterranean fisheries. Fish Res 179:57-66

González-Wangüemert M, Domínguez-Godino J, Cánovas F (2018) The fast development of sea cucumber fisheries in the Mediterranean and NE Atlantic waters: from a new marine resource to its over-exploitation. Ocean Coast Man J 151:165-177

Gressler V, Yokoya NS, Fujii MT, Colepicolo P, Torres RP, Pinto E (2010) Lipid, fatty acid, protein, amino acid and ash contents in four Brazilian red algae species. Food Chem 120:585-590

Harper CR, Jacobson TA (2005) Usefulness of omega-3 fatty acids and the prevention of coronary heart disease. Am J Cardiol 96:1521-1529

Harris WS, Miller M, Tighe AP, Davidson MH, Schaefer EJ (2008) Omega-3 fatty acids and coronary heart disease risk: clinical and mechanistic perspectives. Atherosclerosis 197:12-24

Ikeda A, Imaizumi K, Sugano M (1993) Interaction of dietary protein and fat on plasma cholesterol and amino acid levels, fatty acid desaturation, and prostacyclin production in exogenous hypercholesterolemic rats. Biosci Biotechnol Biochem 57:1867-1872

INFOPESCA and FAO (2013) http://www.infopesca.org/. Accessed 20 Dec 2017

Jaquemet S, Conand C (1999) The bêche-de-mer trade in 1995-96 and an assessment of exchanges between the main world markets. SPC Bêche-de-Mer Inf Bull 12:11-14

Kasai T (2003) Lipid contents and fatty acid composition of total lipid of sea cucumber Stichopus japonicus and konowata (salted sea cucumber entrails). Food Sci Technol Res 9:45-48

Khodabux K, L'Omelette MSS, Jhaumeer-Laulloo S, Ramasami P, Rondeau P (2007) Chemical and near-infrared determination of moisture, fat and protein in tuna fishes. Food Chem 102:669-675

Kinch J, Purcell S, Uthicke S, Friedman K (2008) Population status, fisheries and trade of sea cucumbers in the Western Central Pacific. In: Toral-Granda V, Lovatelli A, Vasconcellos M (eds) Sea cucumbers: a global review of fisheries and trade. FAO fisheries and aquaculture technical paper no. 516. FAO, Rome, pp 7-55

Lah RA, Smith J, Savins D, Dowell A, Bucher D, Benkendorff K (2017) Investigation of nutritional properties of three species of marine turban snails for human consumption. Food Sci Nutr 5:14-30

Lebreton B, Richard P, Galois R, Radenac G, Pfléger C, Guillou G, Mornet F, Blanchard GF (2011) Trophic importance of diatoms in an intertidal Zostera noltii seagrass bed: evidence from stable isotope and fatty acid analyses. Estuar Coast Shelf Sci 92:140-153

Lepage G, Roy CC (1984) Improved recovery of fatty acid through direct transesterification without prior extraction or purification. J Lipid Res 25:1391-1396

Mahomoodally MF, Muthoorah LD (2014) An ethnopharmacological survey of natural remedies used by the Chinese community in Mauritius. Asian Pac J Trop Biomed 4:S387-S399

Marín-Guirao L, Cesar A, Marín A, Lloret J, Vita R (2005) Establishing the ecological quality status of soft-bottom miningimpacted coastal water bodies in the scope of the Water Framework Directive. Mar Pollut Bull 50:374-387

Mootoosamy A, Mahomoodally MF (2014) A quantitative ethnozoological assessment of traditionally used animal-based therapies in the tropical island of Mauritius. J Ethnopharmacol 154:847-857

Njinkoue JM, Gouado I, Tchoumbougnang F, Yanga Ngueguim JH, Ndinteh DT, Fomogne-Fodjo CY, Schweigert FJ (2016) Proximate composition, mineral content and fatty acid profile of two marine fishes from Cameroonian coast: Pseudotolithus typus (Bleeker, 1863) and Pseudotolithus elongatus (Bowdich, 1825). NFS J 4:27-31

Parrish C, Abrajano T, Budge S, Helleur R, Hudson E, Pulchan K, Ramos C (2000) Lipid and phenolic biomarkers in marine ecosystems: analysis and applications. Mar Chem 5:193-223 
Pereira H, Barreira L, Custódio L, Alrokayan S, Mouffouk F, Varela J, Abu-Salah KM, Ben-Hamadou R (2013) Isolation and fatty acid profile of selected microalgae strains from the Red Sea for biofuel production. Energies 6:2773-2783

Purcell S (2010) Managing sea cucumber fisheries with an ecosystem approach. FAO fisheries and aquaculture technical paper, 520

Purcell SW (2014) Value, Market preferences and trade of beche-de-mer from Pacific Island sea cucumbers. PLoS ONE 9:e95075. https://doi.org/10.1371/journal.pone.0095075

Purcell SW, Samyn Y, Conand C (2012) Commercially important sea cucumbers of the world, vol 6. FAO species catalogue for fishery purposes. FAO, Rome

Purcell SW, Conand C, Uthicke S, Byrne M (2016) Ecological roles of exploited sea cucumbers. Oceanogr Mar Biol Annu Rev $54: 367-386$

Ramón M, Lleonart J, Massutí E (2010) Royal cucumber (Stichopus regalis) in the northwestern Mediterranean: distribution pattern and fishery. Fish Res 105:21-27

Roggatz C, González-Wangüemert M, Pereira H, Barreira L, Rodrigues MJ, Moreira da Silva M, Varela J, Custódio L (2016) First report of the nutritional profile and antioxidant potential of Holothuria arguinensis, a new resource for aquaculture in Europe. Nat Prod Res 9:1-7

Rohling EJ, Marino G, Grant KM (2015) Mediterranean climate and oceanography, and the periodic development of anoxic events (sapropels). Earth Sci Rev 143:62-97

Roynette CE, Calder PC, Dupertuis YM, Pichard C (2004) n-3 Polyunsaturated fatty acids and colon cancer prevention. Clin Nutr 23:139-151

Sánchez-Machado DI, López-Cervantes J, López-Hernández J, Paseiro-Losada P (2004) Fatty acids, total lipid, protein and ash contents of processed edible seaweeds. Food Chem 85:439-444

Sandrini-Neto L, Camargo MG (2011) GAD: an R package for ANOVA designs from general principles. Available on CRAN. http://ftp5.gwdg.de/pub/misc/cran/. Retrieved 01 May 2012

Schmitz G, Ecker J (2008) The opposing effects of n-3 and n-6 fatty acids. Prog Lipid Res 47:147-155

Sicuro B, Piccino M, Gai F, Abete MC, Danieli A, Dapra F, Miolettiu S, Vilella S (2012) Food quality and safety of Mediterranean sea cucumbers Holothuria tubulosa and Holothuria polii in Southern Adriatic Sea. Asian J Anim Vet Adv 7:851-859

Storelli MM, Storelli A, Marcotrigiano GO (2001) Heavy metals in the aquatic environment of the Southern Adriatic Sea, Italy: macroalgae, sediments and benthic species. Environ Int 26:505-509

Tunca E, Aydın M, Şahin Ü (2016) Interactions and accumulation differences of metal(loid)s in three seacucumber species collected from the Northern Mediterranean Sea. Environ Sci Pollut Res Int 23(20):21020-21031

Warnau M, Dutrieux S, Ledent G, Rodriguez y Baena AM, Dúbois P (2006) Heavy metals in the sea cucumber Holothuria tubulosa (Echinodermata) from the Mediterranean Posidonia oceanica ecosystem: body compartment, seasonal, geographical and batymetric variations. Environ Bioindic 1:268-285

Weis J, Weis P (2004) Metal uptake, transport and release by wetland plants: implications for phytoremediation and restoration. Environ Int 30:685-700

Wen J, Hu C, Fan S (2010) Chemical composition and nutritional quality of sea cucumbers. J Sci Food Agric 90:2469-2474

Yu HB, Gao QF, Dong SL, Wen B (2015) Changes in fatty acid profiles of sea cucumber Apostichopus japonicus (Selenka) induced by terrestrial plants in diets. Aquaculture 442:119-124

Zhong Y, Khan M, Shaidi F (2007) Compositional characteristics and antioxidant properties of fresh and processed sea cucumber (Cucumaria frondosa). J Agric Food Chem 55:1188-1192

\section{Publisher's Note}

Springer Nature remains neutral with regard to jurisdictional claims in published maps and institutional affiliations. 